\title{
Pituitary gonadotrophins in Booroola and control Merino sheep
}

\author{
D. M. Robertson, Susan Ellis, Lynda M. Foulds, J. K. Findlay* \\ and B. M. Bindon $\dagger$
}

Department of Anatomy, Monash University, Clayton, Victoria 3168; *Medical Research Centre, Prince Henry's Hospital, Melbourne, Victoria 3004 and †C.S.I.R.O. Division of Animal Production, Armidale, New South Wales 2350, Australia

\begin{abstract}
Summary. Pituitary content of FSH and LH, using radioreceptor assay methods, was determined in control and Booroola Merino ewes on the 3rd day of the oestrous cycle and in adult rams slaughtered in winter. Significantly more pituitary FSH (as per gland or per $g$ wet $w t$ ) was found in the Booroola than in the control ewe. No significant differences were found in $\mathrm{LH}$ content although the difference in $\mathrm{FSH} / \mathrm{LH}$ ratio between Booroola and control ewes was significant $(P<0.001)$. Pituitary FSH content was similar in the rams of the two genotypes.

A good correspondence between FSH values by the radioreceptor assay and by radioimmunoassays using anti-ovine and anti-human serum was observed for the Booroola ewes. However, radioimmunological estimates of FSH activity were significantly higher than radioreceptor estimates in control ewes and in Booroola and control rams in which the pituitary FSH values were $5-6 \%$ of that of the ewe. This overestimation is attributed to differences in specificity between methods. Fractionation of pituitary extracts by electrofocussing indicated a similar pI profile of FSH for ewes and rams of both genotypes.

It is concluded that quantitative rather than qualitative differences in pituitary FSH occur in Booroola and control Merino ewes. It is suggested that increased FSH levels contribute to the hormonal basis for the increased ovulation rate of the Booroola Merino.
\end{abstract}

\section{Introduction}

The prolificacy of the Booroola Merino is well established (Turner, 1978) and individual ewes can have up to 11 ovulations (Bindon \& Piper, 1982). It has been proposed that a major gene is responsible for the extremes in ovulation rate within the Booroola flock (Piper \& Bindon, 1982) and three putative genotypes, FF (homozygous carriers of the fecundity gene), F+ (heterozygous carriers) and ++ (non-carriers) have been proposed, based on maximum ovulation rates of $>5$, $<5$ and $>3$ and $<3$ respectively, assessed from repeated observations (Davis, Montgomery, Allison, Kelly \& Bray, 1982).

An hormonal basis for the increased ovulation rate in the Booroola Merino has not been established. Several lines of evidence point to a role for follicle-stimulating hormone (FSH) in the mechanisms controlling follicular growth and ovulation rate in sheep. These include the effects of hypophysectomy on ovarian follicular populations (Dufour, Cahill \& Mauléon, 1979) and of exogenous FSH on ovulation rate (Betteridge, 1981; Wright, Bondoli, Grammer, Kuzan \& 
Menino, 1981), and demonstrations that plasma FSH concentrations are elevated before ovulation in sheep with increased ovulation rates induced by supplementation of the diet with lupins (Brien, Baxter, Findlay \& Cumming, 1976; Davis, Brien, Cumming \& Findlay, 1981; Knight, Payne \& Peterson, 1981). Also, compensatory ovulation after unilateral ovariectomy is associated with a transient increase in FSH secretion (Findlay \& Cumming, 1977). The inhibin content of the ovaries of Booroola ewes is only one third that of control Merinos (Cummins, O'Shea, Bindon, Lee \& Findlay, 1983), suggesting that peripheral FSH concentrations in Booroola ewes are likely to be higher than in control ewes. However, attempts to establish a relationship between peripheral FSH concentrations and ovulation rate in the adult Booroola Merino during the oestrous cycle have been unsuccessful (Bindon, Findlay \& Piper, 1982), despite earlier observations that prepubertal Booroola ewe lambs have higher peripheral FSH concentrations than do control Merinos (Findlay \& Bindon, 1976). Furthermore, attempts to relate peripheral FSH levels to genetic merit of males, based on dams' ovulation rate, have also been unsuccessful (Findlay \& Bindon, 1976; Bindon et al., 1984).

The failure to observe hormonal correlates of ovulation rate in sheep, including the Booroola (Findlay \& Cumming, 1976; Scaramuzzi \& Radford, 1983), can be explained in several ways. Firstly, that methodological problems with the hormone assays, for FSH in particular, prevent an accurate assessment of the levels of biologically active circulating gonadotrophin. Secondly, that the time of the oestrous cycle at which the observations on gonadotrophins were made was inappropriate; and, thirdly, that it is the type of gonadotrophin rather than the amount that influences the number of follicles which ovulate.

The possibility that qualitative as well as quantitative differences in FSH may exist between genotypes was indicated by previous findings of differences in a number of properties of FSH and LH obtained from animals of the two sexes after endocrine manipulations: These differences, in terms of pI (Wide, 1981; Chappel, 1981; Robertson, Foulds \& Ellis, 1982), apparent size (Bogdanove, Campbell \& Peckham, 1974; Blum \& Gupta, 1980) and circulatory half life (Bogdanove et al., 1974), may influence the overall biological activity of the molecule. Electrofocussing is a technique well suited for the separation of the different isoforms of pituitary gonadotrophins.

The purpose of this study was (a) to measure the content of FSH and LH in pituitaries of Booroola and control Merino ewes and rams by radioreceptor assay and radioimmunoassay, (b) to compare a heterologous and an homologous radioimmunoassay with the radioreceptor assay for ovine pituitary FSH, and (c) to assess whether there was a qualitative difference in the pituitary FSH content as determined by an electrofocussing technique in ewes and rams of the two genotypes.

\section{Materials and Methods}

Animals. The Booroola Merino and random-bred control Merino flocks have been described in detail by Turner (1978). For the present study Booroola ewes aged 8 years were chosen, on the basis of 2-8 separate ovulation rate records, as being carriers of the Booroola gene $(F / F$ and $F /+)(D a v i s$ et al., 1982). These ewes $(\mathrm{N}=7)$ and age-matched ewes $(\mathrm{N}=7)$ from the control Merino flock were slaughtered in June on Day 3 of a normal oestrous cycle (day of oestrus is Day 1). Pituitary glands were removed within $10 \mathrm{~min}$ of slaughter, then trimmed, weighed and frozen in a $\mathrm{CO}_{2} /$ ethanol mixture within the next $50 \mathrm{~min}$.

Booroola rams, aged 3 years, were chosen on the basis of pedigree as being probable carriers of the Booroola gene. The dams of all 8 Booroola rams studied had at least one ovulation record of 5 or more. These rams and age-matched control rams $(N=8)$ were killed in June which represents the approximate trough of the Merino sexual season in Armidale as assessed from the pattern of testicular growth of Merinos (Edey, Ketut-Sutama \& Raadsma, 1983). Pituitary glands were processed as described above. 
Pituitary extracts. All subsequent operations were performed at $4^{\circ} \mathrm{C}$. Individual pituitaries were minced and homogenized in $10 \%(\mathrm{w} / \mathrm{v}) 10 \mathrm{~mm}$-phosphate buffer $\mathrm{pH} 7.0$ containing $0.1 \%$ bovine serum albumin using a tissue disperser (Ultra Turrex; Janke \& Kunkel K.G., Staufen, West Germany); a $105000 \mathrm{~g}$ supernatant was prepared. Aliquots of each extract studied were combined to make 4 pools, one for each of the 4 animal groups, for use in the electrofocussing studies and in assessment of parallelism with the various hormone assays. Individual and pooled extracts were divided into aliquots, snap frozen in a solid $\mathrm{CO}_{2} /$ ethanol mixture and stored at $-20^{\circ} \mathrm{C}$.

Hormone preparations. Ovine FSH (NIH-FSH-S6: biological activity $1.24 \times \mathrm{NIH-FSH}-\mathrm{S} 1$ ), ovine LH (NIH-LH-S23: 2.3 × NIH-LH-S1) and hCG (CR-121, 11600 i.u./mg) were obtained from the NIAMDD, NIH, Bethesda, MD, U.S.A. Human FSH (AFP4161 B: 5200 i.u./mg, by FSH radioreceptor assay with 1st IRP pituitary $\mathrm{FSH} / \mathrm{LH}$ for bioassay as standard) and ovine FSH (AFP5679C) used as tracer were obtained from Dr A. F. Parlow, Torrance, California, U.S.A.

Radioreceptor assays. For FSH, the method of Cheng (1975) was employed with NIH-FSH-S6 as standard and iodinated human FSH as tracer. The within-assay variation, for this study, as assessed from the mean index of precision (Gaddum, 1933), was 0.053 and the between-assay variation was $15.5 \%$. The sensitivity of the assay, defined as the mass of standard/tube giving an $\mathrm{ED}_{10}$, was $1.7 \pm 0.2 \mathrm{ng}$ FSH. Previous studies (Cheng, 1975; Van Damme, Robertson, Marana, Ritzén \& Diczfalusy, 1979; Marana, Robertson, Suginami \& Diczfalusy, 1979a) of the assay with human and ovine FSH preparations have shown that this method is specific for FSH activity. The influence of tissue proteases was assessed by comparing potency estimates of the four pools when assayed in the presence or absence of protease inhibitors (final conc. $1 \mu \mathrm{g}$ phenyl methyl sulphonyl fluoride/ml and $6.25 \mu \mathrm{g}$ methylmaleimide $/ \mathrm{ml}$. No significant differences in potency estimates in the presence or absence of the inhibitors were observed.

For LH, the method of Leidenberger \& Reichert (1972) was employed using iodinated hCG as tracer and NIH-LH-S23 as standard. The within-assay variation as assessed from the index of precision was 0.080 . The sensitivity of the assay as defined above was $0.6 \pm 0.2 \mathrm{ng} \mathrm{LH}$. All samples were assayed in the one assay.

Parallelism between logit log-dose transformed response lines was observed between the standard and the 4 pituitary extract pools in each of the above radioreceptor assays.

Radioimmunoassays. Two antisera, against ovine FSH (NIAMDD anti-oFSH-1) and human FSH (59/7, Bremner, Findlay, Lee, de Kretser \& Cumming, 1980), were studied. A 24-h simultaneous addition assay at $4^{\circ} \mathrm{C}$ with iodinated ovine FSH (AFP5679C) as tracer and NIHFSH-S6 as standard was used with both antisera. The hormone for tracer was iodinated by the chloramine-T procedure and purified free of iodinated subunits and aggregates by fractionation on a high-resolution gel-filtration column (see Marana, Suginami, Robertson \& Diczfalusy, 1979b). The sensitivities of the homologous and heterologous assay systems, defined as the mass of standard/tube giving an $\mathrm{ED}_{10}$, were $0.8 \pm 0.3 \mathrm{ng}$ and $15 \pm 5 \mathrm{ng} \mathrm{FSH}$ respectively. The corresponding within-assay variations as assessed from the mean index of precision, were 0.080 and 0.079 respectively, and the between-assay variations were 6.6 and $9.6 \%$, respectively. With the anti-hFSH serum parallelism was observed between logit log-dose transformed response lines of the standard and all 4 pituitary extract pools, while non-parallelism was observed with several pituitary extracts with the anti-oFSH serum. Further details are presented in the 'Results' and Table 2.

Electrofocussing. A microelectrofocussing procedure in sucrose gradients (Robertson et al., 1982; Foulds \& Robertson, 1983) was used in the $\mathrm{pH}$ range 3.5-10. In brief, an aliquot of each pituitary extract ( $200 \mu \mathrm{l}$ and $800 \mu \mathrm{l}$ from the ewe and ram respectively) was electrofocussed for 20 $24 \mathrm{~h}$ at $4^{\circ} \mathrm{C}$. The column was eluted, the $\mathrm{pH}$ profile determined and each fraction was gel filtered to remove sucrose and carrier ampholytes before radioreceptor assay and radioimmunoassay. The reproducibility of the electrofocussing procedure was assessed from the reproducibility of the pI 
value of a marker protein, bovine haemoglobin $(7 \cdot 51 \pm 0 \cdot 12$, s.d., $n=7)$, co-electrofocussed with the pituitary extracts. The mean \pm s.d. recovery of radioreceptor active FSH after electrofocussing of the 4 pituitary extracts was $61 \pm 3 \%$. Recovery of FSH immunoactivity using the ovine FSH antiserum with the Booroola ewe extract was $42 \%$. Assessment of recoveries of immunoactivity after electrofocussing with the other pituitary extracts was not attempted since these extracts gave dose-response lines that were not parallel with the standard. The profile of FSH immunological activity using the human FSH antiserum was not determined because this method was largely insensitive to the levels of FSH found over the chromatogram.

Statistical analysis. Parallelism between standard and unknown was established from the statistical comparison by 2-way analysis of variance of slope values from 3 or more assays. The dose-response lines, consisting of 4-6 doses with a dose interval of 2 , were linearized following a logit log-dose transformation. Once parallelism was established the potency estimates for the unknown preparations were calculated using standard bioassay statistical designs. For those samples for which the dose-response lines were not parallel with the standard, a logit 0 value (equivalent to $\mathrm{ED}_{50}$ ) of the unknown in terms of the standard was determined. Comparison between groups was made using the ranking test of Kramer (1956) or by paired $t$ test.

\section{Results}

\section{Radioreceptor assay of pituitary content of FSH and LH}

The pituitary FSH content in Booroola ewes was significantly $(P<0.05)$ higher than in control ewes (Table 1). No corresponding differences were observed for LH whether expressed as per pituitary or per unit wet weight. However, a significant $(P<0.001)$ difference in FSH : LH ratio was observed between ewe genotypes. The equivalent comparisons of pituitary FSH and LH between genotypes of ram were not statistically different. However, the control and Booroola ewes had 12- to 14-fold more FSH and 2- to 5-fold more LH (on a wet weight basis) than did rams.

Table 1. The mean ( \pm s.d.) pituitary content of FSH and LH as measured by radioreceptor assay in control and Booroola Merino sheep

\begin{tabular}{|c|c|c|c|c|c|c|c|c|}
\hline \multirow[b]{2}{*}{ Genotype } & \multirow[b]{2}{*}{$\begin{array}{c}\text { Age } \\
\text { (years) }\end{array}$} & \multirow[b]{2}{*}{ No. } & \multirow{2}{*}{$\begin{array}{l}\text { Pituitary } \\
\text { wet wt } \\
\text { (mg) }\end{array}$} & \multicolumn{2}{|c|}{ FSH } & \multicolumn{2}{|c|}{ LH } & \multirow[b]{2}{*}{ FSH :LH } \\
\hline & & & & $\begin{array}{c}\mu \mathrm{g} / \\
\text { pituitary }\end{array}$ & $\begin{array}{c}\mu \mathrm{g} / \\
\mathrm{g} \text { wet wt }\end{array}$ & $\begin{array}{c}\mu \mathrm{g} / \\
\text { pituitary }\end{array}$ & $\begin{array}{c}\mu \mathrm{g} / \\
\mathrm{g} \text { wet wt }\end{array}$ & \\
\hline $\begin{array}{l}\text { Control ewe } \\
\text { Booroola ewe }\end{array}$ & $\begin{array}{l}8 \\
8\end{array}$ & $\begin{array}{l}7 \\
7\end{array}$ & $\begin{array}{l}719 \pm 276 \\
739 \pm 176\end{array}$ & $\begin{array}{l}485 \pm 156 \\
933 \pm 403^{*}\end{array}$ & $\begin{array}{c}764 \pm 374 \\
1234 \pm 348^{*}\end{array}$ & $\begin{array}{r}1186 \pm 518 \\
864 \pm 499\end{array}$ & $\begin{array}{l}1880 \pm 1180 \\
1185 \pm 676\end{array}$ & $\begin{array}{l}0.39 \pm 0.09 \\
1.26 \pm 0.53^{* * *}\end{array}$ \\
\hline $\begin{array}{l}\text { Control ram } \\
\text { Booroola ram }\end{array}$ & $\begin{array}{l}3 \\
3\end{array}$ & $\begin{array}{l}8 \\
8\end{array}$ & $\begin{array}{l}553 \pm 101 \\
501 \pm 52\end{array}$ & $\begin{array}{l}29 \cdot 2 \pm 28 \cdot 7 \\
49 \cdot 4 \pm 27 \cdot 4\end{array}$ & $\begin{array}{r}49 \cdot 8 \pm 41 \cdot 9 \\
101 \pm 59 \cdot 8\end{array}$ & $\begin{array}{l}205 \pm 121 \\
226 \pm 123\end{array}$ & $\begin{array}{l}371 \pm 216 \\
468 \pm 283\end{array}$ & $\begin{array}{l}0.15 \pm 0.09 \\
0.26 \pm 0.16\end{array}$ \\
\hline
\end{tabular}

${ }^{*} P<0.05 ;{ }^{* *} P<0.001$, compared with value for control ewes.

\section{Pituitary content of immunoactive FSH}

Studies on the validity of the ovine FSH radioimmunoassay procedure using an ovine FSH-antiserum showed evidence of non-parallelism between the standard (NIH-oFSH-S6) and 3 of the 4 pituitary pools and a purified ovine FSH preparation (Table 2). In contrast, parallelism of these pools with the same standard preparation was observed with a radioimmunoassay using a human FSH antiserum (Table 2).

A comparison of the pituitary levels (per pituitary or as $g$ wet wt) of immunoactive FSH, as determined with both antisera, showed no significant differences between genotype with either sex. A further comparison of the pituitary FSH levels between genotype, using the NIAMDD ovine 


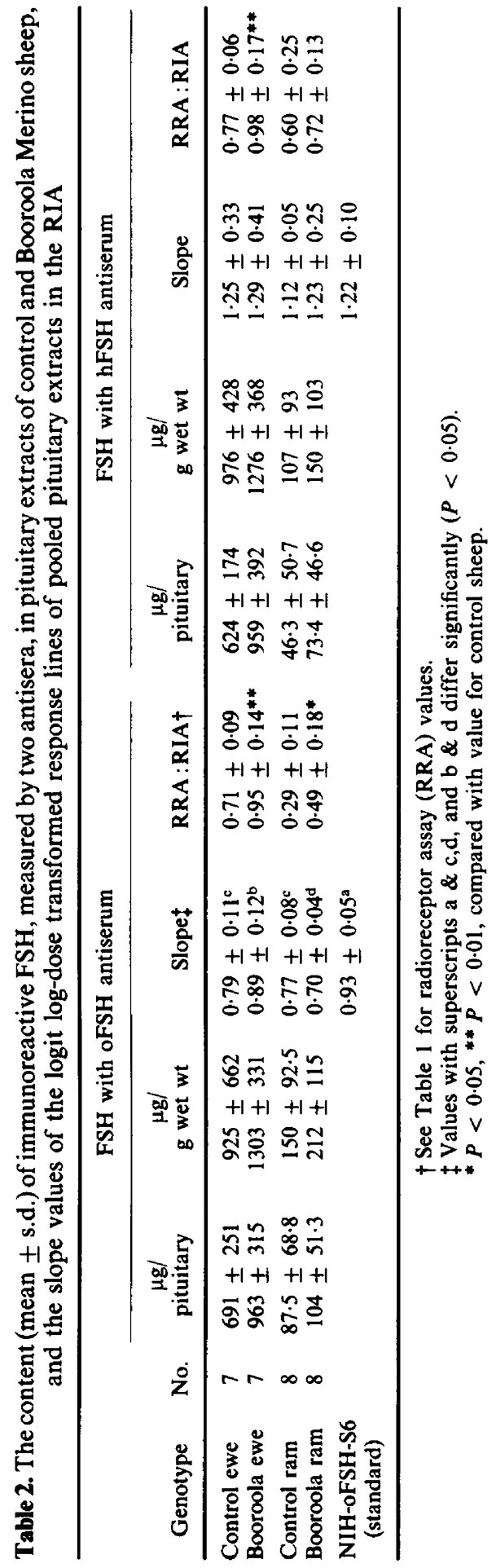


FSH radioimmunoassay kit and employing the same ovine FSH antiserum as used in this study, was made at Armidale with a larger sample size $(n=14)$ of 2-year-old control and Booroola Merino ewes. Significantly $(P<0.01)$ higher FSH levels, expressed on a per gland and per $\mathrm{g}$ wet weight basis, were found in the Booroola ewes.

The content of immunoactive FSH was higher in ewes than rams, irrespective of the antiserum used, and therefore reflected the data using the radioreceptor assay for FSH.

The ratio of pituitary FSH radioreceptor activity:immunoactivity significantly $(P<0.01)$ decreased from approximately unity $(0.95)$ in the Booroola ewe to 0.71 in the control ewe when using the ovine FSH antiserum (Table 2). Lower ratios $(0.49$ and 0.29$)$ were found with the corresponding male genotypes. Similar differences in these ratios were observed between female genotypes with the corresponding 4 animal groups with the human FSH antiserum.

Regression analysis of the pituitary FSH levels of all animal groups by radioreceptor assay and each of the two radioimmunoassays resulted in slope values of the regression line $(1.05)$ being statistically indistinguishable from unity (Text-fig. 1). However, the intercept value $(0.12 \pm 0.04$ $\mathrm{mg} \mathrm{FSH} / \mathrm{g}$ wet $\mathrm{wt}$ ) of the regression line on the $y$ (radioimmunoassay) axis was significantly greater than zero when using the ovine FSH antiserum, in contrast to that obtained with the human FSH antiserum. This is reflected by the fact that the anti-ovine FSH serum measured significantly $(P<$ $0.05)$ more immunoreactivity in pituitary extracts of the males than did the assay using anti-human FSH serum (Table 2) as assessed by paired $t$ test analysis.

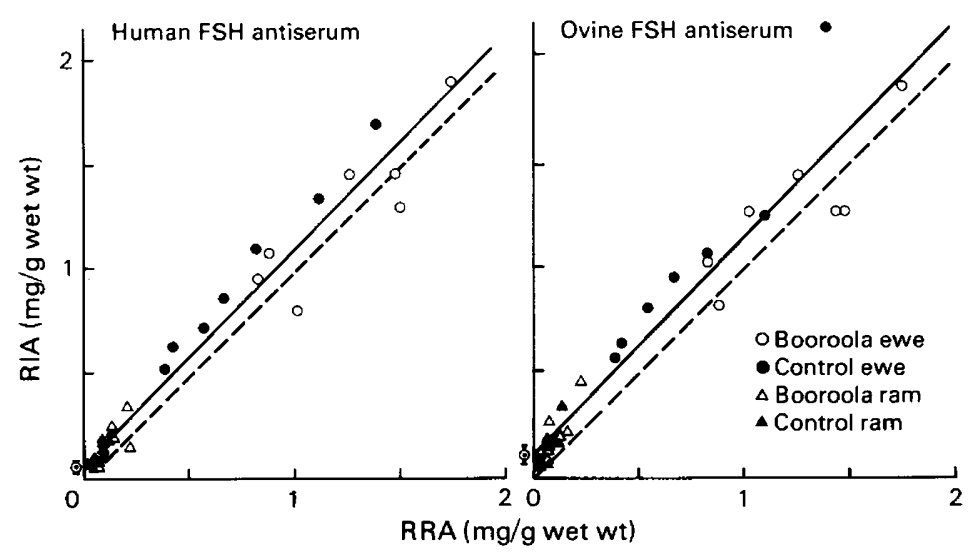

Text-fig. 1. Regression analysis of pituitary FSH when assayed by radioreceptor assay (RRA) and by radioimmunoassay (RIA) using two antisera. The broken $45^{\circ}$ line is included for comparison with the calculated regression line.

\begin{tabular}{|c|c|c|}
\hline & hFSH antiserum & oFSH antiserum \\
\hline Correlation coefficient & 0.98 & 0.96 \\
\hline Slope \pm s.e. & $1.05 \pm 0.04$ & $1.05+0.06$ \\
\hline $\begin{array}{l}y \text { intercept } \pm \text { s.e. } \\
\text { (mg FSH/g wet wt) }\end{array}$ & $0.06 \pm 0.03$ & $0.12 \pm 0.04$ \\
\hline
\end{tabular}

\section{Electrofocussing fractionation of pituitary $\mathrm{FSH}$}

The $\mathrm{pI}$ distribution of radioreceptor active FSH showed a similar pattern between genotype for both sexes (Text-figs $2 \mathrm{a} \& 2 \mathrm{~b}$ ). Furthermore, the pI distribution of immunoactive FSH using the ovine FSH antiserum showed a pattern similar to that observed with radioreceptor active FSH, although high base-line levels of immunoactive FSH were noted in the ram in regions devoid of radioreceptor activity. 

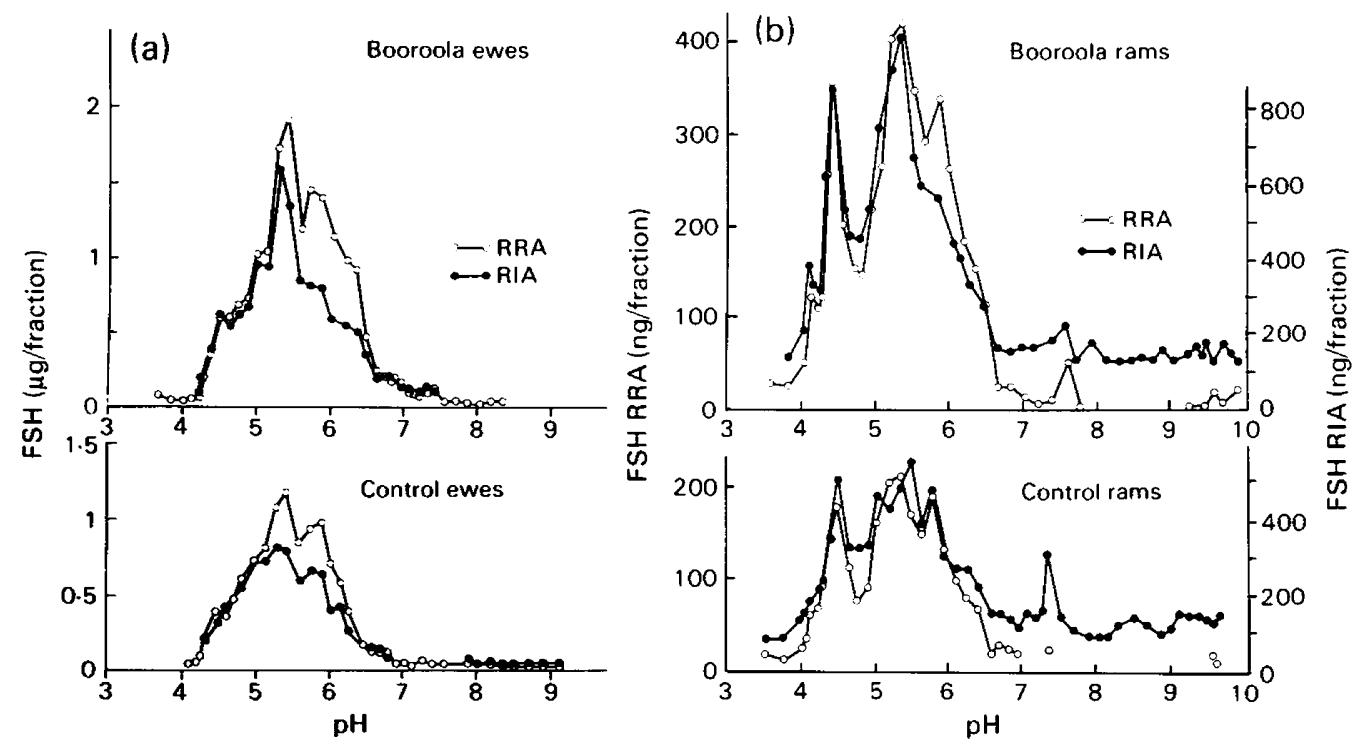

Text-fig. 2. The pH distribution of pituitary FSH from control and Booroola Merino ewes (a) and rams (b) as measured by radioreceptor assay (RRA) and a radioimmunoassay (RIA) using an ovine FSH antiserum. The FSH standard was NIH-oFSH-S6.

\section{Discussion}

The pituitary content of FSH on the 3rd day of the oestrous cycle was significantly higher in Booroola ewes than in control ewes and this difference was amplified when expressed as the ratio of radioreceptor FSH to LH. The elevated pituitary FSH content of Booroola ewes is consistent with the lower inhibin content of the ovaries of these animals (Cummins et al., 1983), assuming that the ovarian inhibin content is reflected in the peripheral inhibin levels reaching the pituitary gland to suppress FSH synthesis and release. The elevated pituitary FSH content as determined by radioreceptor assay of Booroola ewes is also consistent with a dose-dependent relationship between FSH and ovulation rate. In fact, there was a significant correlation $(r=0.84, n=14, P<0.01)$ between pituitary FSH/LH ratios and ovulation rate (i.e. the mean of several records from each ewe) for the combined Booroola and control ewes, although the correlations within Booroola and control ewes were not significant.

There was a major difference in pituitary FSH content between the sexes although the comparison is confounded by differences in ages of ewes and rams (Table 1). The lower FSH content in the male could be a real effect, since it is consistent with relatively low plasma FSH concentrations in adult rams (Bremner et al., 1980; Bindon et al., 1984), perhaps reflecting the constant feedback suppression of pituitary function by testicular androgens and inhibin.

The results of the electrofocussing studies indicated that the pI profile of pituitary FSH for both genotypes appear qualitatively similar for both sexes and that there was close correspondence between the profile of radioreceptor and immunological activity.

The comparison of the radioreceptor and radioimmunoassays for the measurement of pituitary FSH has provided a reason why it has not been possible to detect differences in plasma FSH in the adult between the two genotypes. Similar results were obtained with both immunoassays and the radioreceptor assay when assaying pituitary extracts containing high FSH levels (Booroola ewe) but an increasing difference (i.e. overestimation by radioimmunoassay) was observed between pituitary FSH levels measured by radioreceptor assay and radioimmunoassay as FSH content 
decreased, more so with the homologous than heterologous radioimmunoassay. The regression analyses of pituitary FSH levels by radioreceptor and radioimmunoassay indicated close correlation between the two methods. However, with the homologous radioimmunoassay in particular, the intercept of the regression line did not pass through zero, indicating the presence of immunoreactive material which was inactive in the radioreceptor system. This material was also evident as a high background in the electrofocussing fractionation of the male pituitaries and could explain the non-parallelism observed with some pituitary extracts using the homologous FSH radioimmunoassay (Table 2). Whether a similar situation with respect to 'blank' material exists with application of the radioimmunoassay procedures to plasma has not been established, mainly because unprocessed plasma cannot be used in the radioreceptor assay for FSH.

This study has indicated that it is the high quantities rather than different qualities of FSH that distinguish the highly prolific Booroola Merino from the less prolific control Merino. Further studies on the FSH to LH ratio in plasma and urine of sheep of these genotypes may further resolve the endocrine differences between them.

We thank M. A. Cheers for technical assistance; NIAMDD and Dr A. F. Parlow for pituitary hormones and antiserum; and the Australian Meat Research Committee, the Australian Wool Corporation and the National Health and Medical Research Council of Australia for financial support.

\section{References}

Betteridge, K.J. (1981) An historical look at embryo transfer. J. Reprod. Fert. 62, 1-13.

Bindon, B.M. \& Piper, L.R. (1982) Physiological characteristics of high fecundity sheep and cattle. In Proc. Wld Cong. Sheep, Cattle Breed., Vol. 1, Technical, pp. 315-331. Eds R. A. Barton \& W. C. Smith. Dunmore Press, Palmerston.

Bindon, B.M., Findlay, J.K. \& Piper, L.R. (1982) Preovulatory plasma FSH in high fecundity Booroola ewes. Proc. Aust. Soc. Reprod. Biol. 14, 84, Abstr.

Bindon, B.M., Piper, L.R., Cummins, L.J., O'Shea, T., Hillard, M.A., Findlay, J.K. \& Robertson, D.M. (1984) Reproductive endocrinology of prolific sheep: studies of the Booroola Merino. In The Genetics of Fecundity. Ed. R. B. Land. Butterworths, London (in press).

Blum, W. \& Gupta, D. (1980) Age and sex-dependent nature of the polymorphic forms of rat pituitary FSH : the role of glycosylation. Neuroendocrinol. Lett. 2, 357-365.

Bogdanove, E.M., Campbell, G.T. \& Peckham, W.D. (1974) FSH pleomorphism in the rat: regulation by gonadal steroids. Endocr. Res. Commun. 1, 87-99.

Bremner, W.J., Findlay, J.K., Lee, V.W.K., de Kretser, D.M. \& Cumming, I.A. (1980) Feedback effects of the testis on pituitary responsiveness to $\mathrm{LH}-\mathrm{RH}$ infusion in the ram. Endocrinology 106, 329-336.

Brien, F.D., Baxter, R.W., Findlay, J.K. \& Cumming, I.A. (1976) Effect of lupin grain supplementation on ovulation rate and plasma follicle stimulating hormone (FSH) concentration in maiden and mature Merino ewes. Proc. Aust. Soc. Anim. Prod. 11, 237240.

Chappel, S.C. (1981) The presence of two species of follicle stimulating hormone within hamster anterior pituitary glands as disclosed by concanavalin A chromatography. Endocrinology 109, 935-942.
Cheng, K.-W. (1975) A radioreceptor assay for follicle stimulating hormone. J. clin. Endocr. Metab. 41, 581589.

Cummins, L.J., O'Shea, T., Bindon, B.M., Lee, V.W.K. \& Findlay, J.K. (1983) Ovarian inhibin content and sensitivity to inhibin in Booroola and control strain Merino ewes. J. Reprod. Fert. 67, 1-7.

Davis, G.H., Montgomery, G.W., Allison, A.J., Kelly, R.W. \& Bray, A.R. (1982) Segregation of a major gene influencing fecundity in progeny of Booroola sheep. N.Z. Jl agric. Res. 25, 525-529.

Davis, I., Brien, F.D., Findlay, J.K. \& Cumming, I.A. (1981) Interactions between dietary protein, ovulation rate and follicle stimulating hormone levels in the ewe. Anim. Reprod. Sci. 4, 19-28.

Dufour, J., Cahill, L.P. \& Mauléon, P. (1979) Short- and long-term effects of hypophysectomy and unilateral ovariectomy on ovarian follicular populations in sheep. J. Reprod. Fert. 57, 301-309.

Edey, T.N., Ketut-Sutama, I. \& Raadsma, H.W. (1983) Seasonal changes in testicular characteristics of rams. Proc. Vth World Conf. Anim. Prod., Tokyo p. 109.

Findlay, J.K. \& Bindon, B.M. (1976) Plasma FSH in Merino lambs selected for fecundity. J. Reprod. Fert. 46, 515-516.

Findlay, J.K. \& Cumming, I.A. (1976) FSH in the ewe: effects of season, liveweight and plane of nutrition on plasma FSH and ovulation rate. Biol. Reprod. 15, 335-342.

Findlay, J.K. \& Cumming, I.A. (1977) The effect of unilateral ovariectomy on plasma gonadotropin levels, estrus and ovulation rate in sheep. Biol. Reprod. 17, 178-183.

Foulds, L.M. \& Robertson, D.M. (1983) Electrofocusing fractionation and characterisation of pituitary follicle-stimulating hormone from male and female rats. Molec. cell. Endocr. 31, 117-130. 
Gaddum, J.H. (1933) Reports in biological standards. III. Methods of biological assay depending on a quantal response. Med. Res. Council Spec. Rep. Ser. No. 183.

Kramer, C.Y. (1956) Extension of multiple range tests to group means with unequal numbers of replications. Biometrics 12, 307-310.

Knight, T.W., Payne, E. \& Peterson, A.J. (1981) Effect of diet and liveweight on FSH and oestradiol concentrations in Romney ewes. Proc. Aust. Soc. Reprod. Biol. 13, 19, Abstr.

Leidenberger, F. \& Reichert, L.E., Jr (1972) Evaluation of a rat testis homogenate radioligand receptor assay for human pituitary LH. Endocrinology 91, 901-909.

Marana, R., Robertson, D.M., Suginami, H. \& Diczfalusy, E. (1979a) The assay of human follicle stimulating hormone preparations: the choice of a suitable standard. Acta endocr., Copenh. 92, 599-614.

Marana, R., Suginami, H., Robertson, D.M. \& Diczfalusy, E. (1979b) Influence of the purity of the iodinated tracer on the specificity of the radioimmunoassay of human follicle stimulating hormone. Acta endocr., Copenh. 92, 585-598.

Piper, L.R. \& Bindon, B.M. (1982) Genetic segregation for fecundity in Booroola Merino sheep. In Proc. Wld Cong. Sheep, Cattle Breed., Vol. 1. Technical, pp. 395-
400. Eds R. A. Barton \& W. C. Smith. Dunmore Press, Palmerston.

Robertson, D.M., Foulds, L.M. \& Ellis, S. (1982) Heterogeneity of rat pituitary gonadotropins on electrofocusing: differences between sexes and after castration. Endocrinology 111, 385-391.

Scaramuzzi, R.J. \& Radford, H.M. (1983) Factors regulating ovulation rate in the ewe. J. Reprod. Fert. 69, 353-367.

Turner, H.W. (1978) Selection for reproduction rate in Australian Merino sheep: direct responses. Aust. $J$. agric. Res. 29, 327-350.

Van Damme, M.-P., Robertson, D.M., Marana, R., Ritzén, E.M. \& Diczfalusy, E. (1979) A sensitive and specific in vitro bioassay method for the measurement of follicle-stimulating hormone activity. Acta endocr., Copenh. 91, 224-237.

Wide, L. (1981) Electrophoretic and gel chromatographic analyses of follicle-stimulating hormone in human serum. Uppsala J. Med. Sci. 86, 249-258.

Wright, R.W., Jr, Bondoli, K., Grammer, J., Kuzan, F. \& Menino, A., Jr (1981) FSH or FSH plus LH super* ovulation in ewes following estrus synchronization with medroxyprogesterone acetate pessaries. J. Anim. Sci. 52, 115-118.

Received 7 September 1983 